\title{
Penanaman Sikap Cinta Lingkungan Melalui Edukasi Pelestarian Ekosistem Mangrove Pada Siswa
}

\author{
Cultivating a Loving Attitude Towards the Environment Through Education of Mangrove \\ Ecosystem Conservation Forstudents
}

${ }^{1)}$ Azza Nuzullah Putri, ${ }^{2)}$ Nevrita, ${ }^{3)}$ Nur Eka Kusuma Hindrasti, ${ }^{4 *}$ Dios Sarkity

${ }^{1,2,3,4)}$ Program Studi Pendidikan Biologi, Fakultas Keguruan dan Ilmu Pendidikan

Universitas Maritim Raja Ali Haji

Jalan Raya Dompak, Pulau Dompak, Tanjungpinang 29111.

*email: diossarkity@umrah.ac.id

DOI:

10.30595/jppm.v5i1.9021

Histori Artikel:

Diajukan:

$13 / 11 / 2020$

Diterima:

$11 / 01 / 2022$

Diterbitkan:

$18 / 02 / 2022$

\section{ABSTRAK}

Siswa sebagai agen perubahan masa depan perlu diberikan edukasi tentang pelestarian lingkungan khususnya ekosistem mangrove. Kegiatan dilakukan dalam bentuk pemberian edukasi dan pengenalan melalui seminar konservasi mangrove. Tujuan dari kegiatan ini adalah untuk menanamkan sikap peduli lingkungan sejak dini sehingga dapat membantu membentuk karakter cinta lingkungan pada siswa. Kegiatan ini diikuti oleh siswa-siswi sekolah menengah yang ada di kota Tanjungpinang dan kabupaten Bintan. Evaluasi dilakukan melalui metode observasi secara langsung kepada siswa-siswi yang telah mengikuti kegiatan ini. Observasi bertujuan untuk melihat keterlibatan siswa dalam aksi peduli lingkungan yaitu pada kegiatan menanam bibit mangrove yang diikuti oleh siswa. Berdasarkan observasi yang dilakukan menunjukkan bahwa kegiatan berjalan dengan baik dan siswa-siswa terlibat secara aktif dalam aksi penanaman sebagai bentuk sikap peduli lingkungan. Mulai dari kegiatan seminar konservasi kemudian dilanjutkan pada aksi penanaman mangrove secara langsung siswa menunjukkan ketertarikan dengan terlibat dalam proses pengambilan bibit, penancapan pancang serta penanaman bibit mangrove.

Kata kunci: Seminar Konservasi Mangrove; Ekosistem Pesisir

\begin{abstract}
Students as agents of future change need to be given education about environmental conservation, especially mangrove ecosystems. Activities carried out in the form of providing education and introduction through mangrove conservation seminars. The purpose of this activity was to instill a caring attitude towards the environment from an early age so that it can help shape the character of loving the environment in students. This activity was attended by high school students in the city of Tanjungpinang and Bintan district. Evaluation was carried out through direct observation to students who had participated in this activity. Observation aimed to see the involvement of students in environmental care actions, namely planting mangrove seedlings, which were followed by students. Based on the observations made, it showed that the activity was going well and the students were actively involved in the planting action as a form of environmental care. Starting from the conservation seminar, then proceeding to the direct mangrove planting action. The students showed interest in being involved in the process of harvesting seeds, planting stakes and planting mangrove seeds.
\end{abstract}

Keywords: Mangrove Conservation Seminar; Coastal Ecosystem 


\section{PENDAHULUAN}

Indonesia merupakan negara maritim terbesar di dunia dengan total wilayah laut sebesar 5,9 juta $\mathrm{km}^{2}$ (United Nations Conventions on the Law of the Sea, 1982). Sebagai negara maritim, Indonesia memiliki banyak potensi wilayah pesisir di berbagai pulau yang tersebar di wilayah Indonesia. Kepulauan riau adalah salah satu provinsi yang memiliki potensi wilayah pesisir yang besar. Hal ini didukung oleh luas wilayah provinsi kepulauan riau sebesar $251.810 \mathrm{~km}^{2}$ dimana 96\% diantaranya merupakan lautan dan $4 \%$ diantaranya merupakan daratan. Dengan jumlah pulau sebanyak 2.408, kepulauan riau memiliki garis pantai sepanjang 2.367,6 km (Ditjen Amerop Kemlu, 2017).

Wilayah pesisir merupakan wilayah peralihan antara ekosistem darat dan laut yang saling berinteraksi. Menurut UU No. 27 Tahun 2007 Tentang batasan wilayah pesisir, kearah daratan mencakup wilayah administrasi daratan dan kearah perairan laut sejauh 12 (dua belas) mil laut diukur dari garis pantai ke arah laut lepas dan/atau kearah perairan kepulauan. Oleh karenanya wilayah ini harus dijaga untuk terhindar dari berbagai kerusakan yang nantinya dapat berdampak pada masyarakat. Salah satu potensi yang dimiliki oleh wilayah kepulauan khususnya daerah pesisir yaitu ekosistem mangrove. Ekosistem mangrove adalah suatu ekosistem yang terletak di tepi pantai dimana lahan ekosistem ini selalu basah karena pasang surut air laut (Senoaji \& Hidayat, 2017).

Ekosistem mangrove memiliki banyak manfaat diantaranya sebagai mitigasi bencana dimana ekosistem mangrove dapat melindungi kawasan pesisir dari gelombang dan angin badai, melindungi pantai dari abrasi, menahan lumpur agar tidak terangkut oleh air ke daratan, intrusi air laut ke daratan serta mencegah pencemaran perairan hingga batas tertentu(Lasibani \& Kamal, 2010). Ekosistem yang umumnya ditemui pada perairan laut dangkal seperti terumbu karang, padang lamun, dan hutan mangrove pada dasarnya dilindungi hal ini dinyatakan di dalam UU No.4/1982 dan UU No. 5/1990. Secara umum hutan bakau atau mangrove mempunyai definisi sebagai hutan yang tumbuh di atas rawa-rawa berair payau yang terletak di garis pantai dan dipengaruhi oleh pasang-surut air laut tepatnya di daerah pantai dan sekitar muara sungai, sehingga tumbuhan yang hidup di hutan mangrove bersifat unik karena merupakan gabungan dari ciri-ciri tumbuhan yang hidup di darat dan di laut.

Kota Tanjungpinang sebagai Ibukota Provinsi Kepulauan Riau memiliki wilayah pesisir yang memiliki potensi ekosistem mangrove seluas 774,25 hektar (Lestari, 2014). Salah satu wilayah Kota Tanjungpinang yang menjadi kawasan ekosistem mangrove adalah kawasan sungai carang. Pada saat ini, ekosistem mangrove di Kawasan sungai carang harus mendapatkan perhatian dari masyarakat karena mengalami kerusakan. Pada umumnya kerusakan ekosistem mangrove secara dominan disebabkan oleh manusia yang melakukan pemanfaatan lahan secara berlebihan (Novianty et al., 2011). Kerusakan eksosistem mangrove di wilayah sungai carang disebabkan oleh pembabatan hutan untuk pembangunan resort (Tanjungpinang pos, 2018). Selain itu kerusakan ekosistem mangrove sungai carang juga disebabkan oleh kegiatan penambangan bauksit (Lestari, 2014).

Pengetahuan mengenai wilayah pesisir penting dimiliki oleh masyarakat yang tinggal di sekitar daerah tersebut. Masyarakat harus mengetahui bagaimana cara menjaga lingkungan pesisir dan juga memahami hal apa saja yang dapat menjadi ancaman pada daerah pesisir. Masyarakat diharakan memiliki kepedulian yang besar terhadap kelestarian wilayah pesisir agar terhindar dari kerusakan. Salah satu upaya yang dapat dilakukan untuk melindungi daerah pesisir yaitu adalah dengan memahami peranan dari ekosistem mangrove yang memiliki banyak manfaat bagi ekosistem pesisir.

Oleh karena itu dalam upaya pelestarian lingkungan, rasa kepedulian terhadap lingkungan sangat dibutuhkan. Sebagai representasi masyarakat masa depan, Siswa sejak dini harus dibekali dengan nilai peduli lingkungan(Subhani et al., 2018). Penanaman nilai peduli lingkungan seperti menanam pohon dan tidak membuang sampah sembarangan 
merupakan salah satu upaya pelaksaan pendidikan karakter (Maunah, 2016). Ketika nilai peduli lingkungan telah dimiliki siswa, maka siswa bukan hanya mampu menjaga lingkungan tetapi siswa juga akan mampu mengajak atau mengingatkan orang lain untuk mau peduli terhadap lingkungan (Al-anwari, 2014).

Salah satu solusi yang dapat diterapkan untuk mengatasi ekosistem mangrove adalah edukasi tentang pelestarian lingkungan pesisir khususnya ekosistem mangrove. Edukasi dengan tema seperti ini sangat penting diberikan khususnya kepada siswa-siswa sekolah di wilayah pesisir seperti Kota Tanjungpinang dan Kabupaten Bintan. Penanaman sikap peduli lingkangan sejak ini dapat menumbuhkan karakter positif yang dapat dibawa oleh siswa saat siswa nantinya terjun ke masyarakat dan menjadi bagian penggerak masyarakat. Berdasarkan permasalahan tersebut, maka kegiatan pengabdian kepada masyarakat dalam bentuk edukasi mengenai pentingnya menjaga kelestarian lingkungan dengan sasaran utama Siswa Sekolah Menengah di Kota Tanjungpinang dan Kabupaten Bintan perlu diadakan. Tujuan kegiatan pengabdian kepada masyarakat ini adalah untuk menanamkan nilai dan tekat pada Siswa sebagai agen perubahan masa depan untuk mau berpartisipasi menjaga dan melestarikan lingkungan khususnya ekosistem mangrove sebagai potensi yang dimiliki wilayah kepulauan.

\section{METODE}

Kegiatan pengabdian kepada masyarakat ini dilaksanakan melalui seminar konservasi mangrove yang diikuti oleh 102 orang siswasiswi Sekolah Menengah di Kota Tanjungpinang dan Kabupaten Bintan. Tahapan pelaksanaan kegiatan pengabdian meliputi: a) Melakukan koordinasi dengan pihak mitra, narasumber dan stakeholder terkait pada kegiatan ini yaitu Pemerintah kota Tanjungpinang, Pemerintah Kepulauan Riau, Rektor UMRAH, Banyan Tree dan Balai Pengolaan Daerah Aliran Sungai dan Hutan Lindung (BPDASHL). Kerjasama ini dilakukan dalam rangka membangun sinergitas untuk bersama-sama dalam meningkatkan kepedulian terhadap lingkungan; b) Mengirimkan undangan kepada Dinas Pendidikan Kota Tanjungpinang dan Kabupaten Bintan; c) Menyebarkan pengumuman dan informasi kegiatan melalui pamflet dan media social; c)Melaksanakan kegiatan seminar konservasi mangrove sebagai kegiatan awal untuk memberikan edukasi tentang pentingnya melestarikan dan menjaga lingkungan khususnya ekosistem mangrove yang merupakan potensi yang dimiliki oleh wilayah pesisir; d) Observasi hasil kegiatan, dilakukan pada saat kegiatan penanaman mangrove yang diikuti oleh siswa-siswi.

Kegiatan seminar konservasi mangrove ini dilaksanakan dalam satu hari dengan menhadirkan 3 pembicara dan dilanjutkan dengan aksi penanaman pada hari berikutnya. Ketiga pembicara menyampaikan materimateri yang berhubungan dengan tema seminar konservasi mangrove. Sebagai bentuk penguatan tekat siswa untuk mau menjaga dan melestarikan lingkungan, kegiatan seminar konservasi mangrove diakhiri dengan ikrar untuk bersedia menerapkan nilai-nilai peduli lingkungan yang diperoleh melalui seminar konservasi mangrove dan ikrar untuk bersedia menjaga dan melestarikan lingkungan seumur hidup.

\section{HASIL DAN PEMBAHASAN}

Pengetahuan mengenai peran mangrove dalam ekosistem pesisir perlu di miliki oleh masyarakat, terutama masyarakat yang berada pada daerah pesisir. Pemberian bekal ini dapat dimulai sedini mungkin seperti pada tingkatan Sekolah Dasar dan Menengah. Hal ini dilakukan agar para siswa dapat mengelola sumber daya yang ada disekitarnya secara bijaksana (Purwanti, 2017). Para siswa diperkenalkan dengan ekosistem mangrove dan perannya bagi wilayah pesisir, kemudian siswa juga dimotivasi untuk dapat peduli dan bisa menjaga lingkungan tempat tinggalnya yang berada di daerah pesisir. Pada kegiatan pengabdian masyarakat yang dilakukan, para siswa diberikan pengenalan melalui kegiatan seminar konservasi. Pada kegiatan ini disajikan gambar-gambar dan video mengenai kondisi lingkungan sekitar daerah pesisir. Selain itu siswa juga disajikan gambaran dampak yang 
dapat terjadi pada kawasan pesisir jika tidak dijaga. Siswa-siswa juga diperkenalkan dengan ekosistem mangrove yang memiliki banyak manfaat dan berperan penting dalam menjaga daerah pesisir.

Pentingnya pemberian wawasan mengenai peran ekosistem mangrove bagi wilayah pesisir bagi siswa-siswa dan masyarakat karena lingkungan ini merupakan lingkungan tempat tinggal mereka dan dimana sebagian besar aktifitas dilakukan disini. Beberapa manfaat ekosistem mangrove bagi kawasan pesisir diantaranya yaitu: mencegah terjadinya intrusi air laut, mencegah terjadinya erosi dan abrasi pantai. Kemudian juga berperan sebagai pencegah dan penyaring alami, tempat hidup dan sumber makanan bagi beberapa jenis satwa, dan juga berperan dalam pembentukan pulau dan menstabilkan daerah pesisir.

Upaya untuk penanaman sikap cinta dan peduli terhadap lingkungan dimulai dengan tahapan pengenalan terhadap lingkungan yang ada disekitar tempat tinggal siswa-siswi. Siswasiswi sebagai bagian dari masyarakat yang tinggal di wilayah Tanjungpinang dan Bintan yang merupakan kawasan pesisir, harus dapat menjaga kelestarian lingkungan ini. Dimulai dari upaya pengenalan berupa kegiatan seminar konservasi, siswa-siswi dapat meningkatkan pengetahuan dan wawasannya terhadap kondisi sekitar. Upaya penanaman sikap cinta dan peduli lingkungan juga akan dilanjutkan dengan penanaman bibit mangrove.

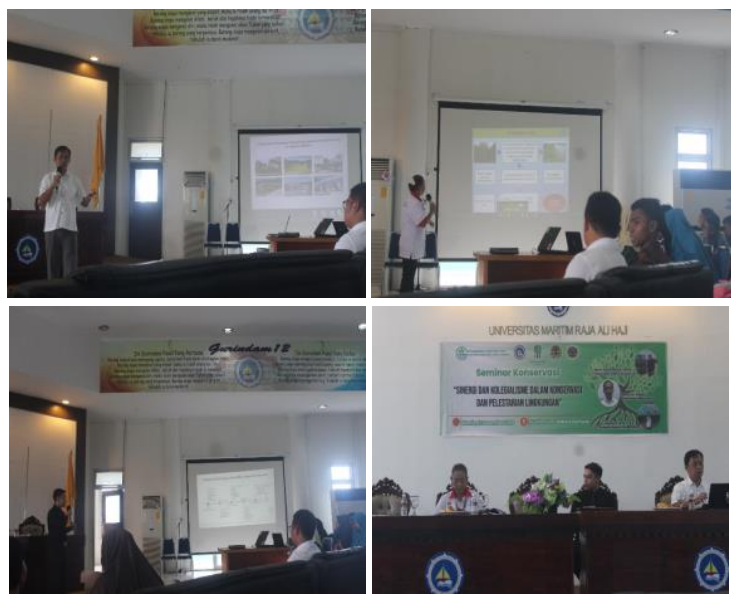

Gambar 1. Penyampaian Materi Seminar Konservasi Mangrove
Kegiatan seminar konservasi mangrove dilaksanakan pada Kamis 12 Desember 2019 dengan tema "Protect The Mangroves That Help Protect Our Island". Kegiatan seminar konservasi Mangrove ini dilaksanaan di Gedung Auditorium Universitas Maritim Raja Ali Haji (UMRAH) Dompak pada pukul 08.30 s.d 12.00. Kegiatan seminar konservasi mangrove ini dihadiri oleh Siswa Sekolah Menengah di Kota Tanjungpinang dan Kabupaten Bintan sebagai sasaran utama kegiatan ini dan juga dihadiri oleh Perwakilan dari Pemerintah Kota Tanjungpinang, Perwakilan dari Pemerintah Provinsi Kepulauan Riau, Rektor Universitas MaritimRaja Ali Haji, Para Guru pendamping, masyarakat umum, serta mahasiswa Universitas Maritim Raja Ali Haji.

\section{1) Materi 1: Corporate social responsibility (CSR)}

Materi pertama yang berjudul Corporate social responsibility (CSR) disampaikan oleh Bapak Henry Al Singer, S.Si yang merupakan CSR Manager Banyan Tree Bintan. Pemateri pertama mewakili para pelaku usaha atau perusahaan yang berada di Kawasan kepualauan. Pada materi pertama, pemateri menyampaikan apa saja tanggung jawab perusahaan pada umumnya serta bagaimana tanggung jawab perusahaan Banyan Tree secara khusus terhadap pelestarian lingkungan pesisir seperti pelestarian ekosistem mangrove. Seperti yang diketahui bahwa kerusakan lingkungan salah satunya disebabkan oleh pelaku usaha atau perusahaan yang secara dominan melakukan pemanfaatan lahan secara berlebihan (Novianty et al., 2011) serta melakukan pembabatan hutan untuk pembangunan resort (Tanjungpinang pos, 2018). Maka melalui topik ini para siswa diberikan edukasi bahwa melestarikan lingkungan merupakan tanggung jawab bersama termasuk juga oleh pala pelaku usaha atau perusahaan. Topik ini diberikan untuk mempersiapkan siswa yang akan terjun ke dunia kerja setelah menempuh berbagai jenjang pendidikan nantinya agar senantiasa menyelaraskan antara pekerjaan dan kepedulian terhadap lingkungan. Siswa diajarkan untuk tidak mengorbankan alam atau mengekploitasi lingkungan secara berlebihan 
hanya demi kebutuhan suatu usaha ataupun pekerjaan.

\section{2) Materi 2: Tantangan Ekosistem Mangrove dalam Era Industri 4.0}

Materi kedua yang berjudul Tantangan Ekosistem Mangrove dalam Era Industri 4.0 diisi oleh Ibu Ir. Sumiati M.Si. Pemateri kedua merupakan Kepala Seksi Rehabilitasi Hutan dan Lahan Balai Pengolaan Daerah Aliran Sungai dan Hutan Lindung (BPDASHL) Sei Jang Duriangkang. Dalam penyampaian materi ini, pemateri menekankan pada bagaimana melestarikan ekosisitem mangrove di era dimana pembangunan dan industry yang semakin maju yang secara tidak langsung memberikan banyak dampak terhadap lingkungan.

Melalui topik ini, pemateri terlebih dahulu memberikan perenungan kepada Siswa secara khusus sebagai target utama seminar konservasi mangrove ini. Pada saat ini, kondisi ekosistem mangrove sudah banyak mengalami kerusakan. Kerusakan yang terjadi sebagaian besar disebabkan oleh ulah tangan manusia. Melalui topik ini juga pada peserta seminar diedukasi tentang apa saja fungsi dari hutan mangrove. Dengan mengenal fungsi hutan mangrove yang sangat besar terhadap lingkungan pesisir, para peserta seminar khususnya Siswa sebagai agen perubahan masa depan menyadari akan pentingnya menjaga dan melestarikan ekosistem dan betapa meruginya manusia akibat perbuatannya dalam merusak dan mengekosploitasi lingkungan. Seiring berkembangnya pembangunan dan industri, maka pentingnya mempersiapkan strategi untuk melaksanakan pembanguann dan industri tetapi tetap memperhatikan baik buruknya terhadap lingkungan. Strategi yang dibuat merupakan pembuatan kebijakan pembangunan dan perindustrian di kawasan pesisir dengan tetap memperhatikan kelestarian ekosistem mangrove.

\section{3) Materi 3: Pendidikan Berdampak Lingkungan.}

Materi ketiga yang berjudul Pendidikan Berdampai Lingkungan disampaikan oleh Bapak Bony Irawan, M.Pd yang merupakan salah satu Dosen Program Studi Pendidikan Biologi Universitas Maritim Raja Ali Haji.
Pemateri ketiga merupakan koordinator rumpun mata kuliah keloompok kajian biologi laut. Melalui keterampilan pedagogik dan ilmu lingkungan yang dimilikinya, pemateri memberikan ilmu tentang bagaimana Mata Pelajaran Biologi seharusnya diajarkan di Sekolah agar memiliki dampak pada karakter cinta lingkungan pada siswa selaku peserta didik.

Kaitannya yang erat dengan lingkungan menjadikan Mata Pelajaran Biologi sebagai sarana yang baik untuk guru dalam menanamkan sikap cinta lingkungan kepada siswa. Guru seharusnya mendesain pembelajaran dengan membuat target sikap cinta lingkungan yang akan ditanamkan melalui setiap topik yang diajarkan pada Mata pelajaran Biologi. Setelah membuat target sikap cinta lingkungan yang akan dibentuk pada siswa melalui pembeajaran, guru dapat mendesain pembelajaran dengan tidak hanya berorientasi pada peningkatan pemahaman konsep siswa tetapi juga penanaman nilai cinta lingkungan dan membentuk karakter cinta lingkungan kepada siswa. Dengan demikian, pembelajaran akan terasa lebih bermakna karena bukan hanya teori-teori saja yang didapatkan oleh siswa melalui pembelajaran tetapi juga karakter yang terbentuk dalam wujud sikap kepedulian terhadap lingkungan yang ditumbuhkan melalui pembelajaran. Melalui materi ketiga ini, pemateri mengedukasi guru pendamping tentang bagaimana membuat pembelajaran biologi yang berdampak lingkungan dan mengedukasi siswa sebagai sasaran utama kegiatan seminar konservasi mangrove untuk meresapi setiap nilai-nilai kepedulian terhadap lingkungan yang ditanamkan melalui pembelajaran sehingga karakter cinta lingkungan dapat ditumbuhkembangkan pada diri siswa. 


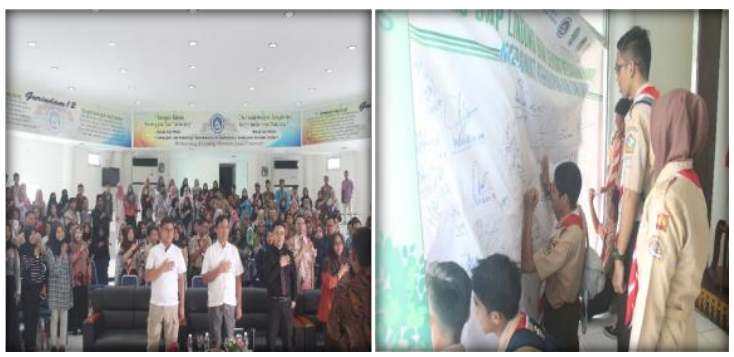

Gambar 2. Ikrar dan penandatanganan ikrar menjaga dan melestarikan lingkungan

Berdasarkan pemaparan ketiga materi yang disampaikan dalam materi, dapat dilihat bahwa di setiap topik yang disampaikan terdapat upaya penanaman sikap cinta lingkungan pada siswa. Penanaman sikap cinta lingkungan ini sejalan dengan upaya sistem pendidikan yang mengupayakan pelaksanaan Pendidikan karakter di Sekolah (Maunah, 2016). Sikap cinta lingkungan ini menjadi penting untuk ditanamkan sejak dini mengingat siswa-siswa di Sekolah merupakan agen perubahan masa depan (Subhani et al., 2018).

Berdasarkan observasi yang dilakukan secara keseluruhan kegiatan berjalan dengan baik. Kegiatan seminar konservasi diikuti dengan antusias oleh para siswa-siswi hal ini dapat dilihat dari keaktifan peserta dalam mengikuti sesi diskusi pada seminar ini. Siswa-siswi mengajukan pertanyaan terkait pelestarian lingkungan kepada pemateri-pemateri seminar. Selain itu para peserta seminar konservasi mangrove juga menunjukkan tekat untuk senantiasa menjaga dan melestarikan lingkungan dengan melakukan ikrar bersama untuk senantiasa berjanji menjaga dan melestarikan lingkungan. Ikrar tersebut juga diwujudkan dalam bentuk pemberian tanda tangan bersama sebagai bukti akan janji untuk menjaga dan melestarikan lingkungan yang telah diucapkan.

Observasi juga dilakukan setelah seminar berlangsung, yaitu pada saat kegiatan penanaman mangrove. Kegiatan ini sangat menyenangkan dan melibatkan siswa secara aktif dalam menanam bibit mangrove yang telah disediakan. Siswa menunjukkan ketertarikan dengan terlibat dalam proses pengambilan bibit, penancapan pancang serta penanaman bibit mangrove.

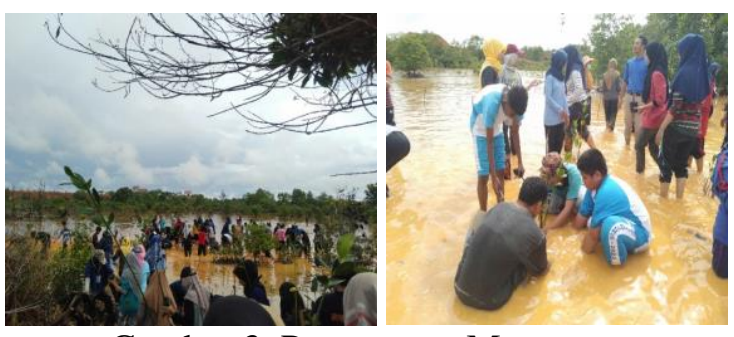

Gambar 3. Penanaman Mangrove

\section{SIMPULAN}

Kegiatan pengabdian masyarakat dalam bentuk seminar konservasi mangrove telah melakukan internalisasi sikap cinta lingkungan melalui edukasi yang diberikan oleh ketiga pemateri seminar. Kegiatan seminar konservasi mangrove ini telah memberikan internalisasi sikap cinta lingkungan dengan sudut pandang yang berbeda yaitu sebagai berikut: dari segi pelaku usaha atau perusahaan yang beroperasi di kawasan kepualauan, dari segi pembuat kebijakan yang memiliki peran penting dalam membuat menciptakan kebijakan-kebijakan yang berdampak baik bagi lingkungan seiring dengan semakin pesatnya pembangunan dan perindustrian, serta sudut pandangan sebagai unsur yang terlibat di dalam kegiatan pembelajaran yang tidak hanya menghasilkan produk pembelajaran berupa pemahaman konsep pada topik tertentu tetapi juga. Kegiatan seminar konservasi mangrove ini juga telah membangkitkan antusias peserta seminar dalam berpatisipasi untuk menjaga dan melestarikan lingkungan yang diwujudkan dalam ikrar bersama dan membuktikannya dalam bentuk tanda tangan. Bagaimana sikap cinta lingkungan yang dibentuk dapat bertahan dan menjadi karakteristik yang melekat pada semua peserta seminar

konservasi mangrove khususnya pada siswa, merupakan tanggung jawab diri sendiri dalam menguatkan tekat serta peran guru dan pihak sekolah untuk terus memberikan edukasi tentang pentingnya menjaga dan melestarikan lingkungan.

\section{DAFTAR PUSTAKA}

Al-anwari, A. M. (2014). Strategi Pembentukan Karakter Peduli Lingkungan Di Sekolah Adiwiyata Mandiri. Ta'dib, 19(02), 227-252. 
Ditjen Amerop Kemlu (2017). Geografis Provinsi Kepualauan Riau.

Ditjen Amerop Kemlu (2017). Geografis Provinsi Kepualauan Riau. https://pasaramerop.kemlu.go.id/id/ne ws/posisi-geografis-provinsi-

kepulauan-riau (diakes November 2019)

Lasibani, S. M., \& Kamal, E. (2010). Pola Penyebaran Pertumbuhan "Propagul" Mangrove Rhozophoraceae di Kawasan Pesisir Sumatra Barat. Jurnal Mangrove Dan Pesisir, 10(1), 33-38.

Lestari, F. (2014). Komposisi Jenis dan Sebaran Ekosistem Mangrove di Kawasan Pesisir Kota Tanjungpinang, Kepulauan Riau. Dinamika Maritim, $I V(\mathrm{I}), 68-75$.

Maunah, B. (2016). Implementasi Pendidikan Karakter Dalam Pembentukan Kepribadian Holistik Siswa. Jurnal Pendidikan Karakter, 1, 90-101. https://doi.org/10.21831/jpk.v0i1.8615

Novianty, R., Sastrawibawa, S., \& Prihadi, D. J. (2011). Identifikasi Kerusakan dan Upaya Rehabilitasi Ekosistem Mangrove di Pantai Utara Kabupaten Subang. Jurnal Akuatika, 2(2), 1-9. https://doi.org/10.4135/978184920940 $3 . n 73$

Purwanti, D. (2017). Pendidikan Karakter Peduli Lingkungan Dan Implementasinya. DWIJA CENDEKIA: Jurnal Riset Pedagogik, 1(2), 14-20. https://doi.org/10.20961/jdc.v1i2.1762 2

Redaksi Tanjungpinang pos. 2018. Mangrova 2,8 Ha Dibabat. http://tanjungpinangpos.id/mangrove28-ha-dibabat/ (diakses 2019)

Senoaji, G., \& Hidayat, M. F. (2017). Peranan Ekosistem Mangrove di Kota Pesisir Bengkulu Dalam Mitigasi Pemanasan Global Melalui Penyimpanan Karbon (The Role of Mangrove Ecosystem in the Coastal City of Bengkulu in Mitigating Global Warming through Carbon sequestration). Jurnal Manusia
Dan Lingkungan, 23(3), 327. https://doi.org/10.22146/jml.18806

Subhani, A., Hadi, H., \& Agustina, S. (2018). Gerakan Sadar Lingkungan (Darling) dan Siap Siaga Bencana (Sigana) Melalui Program Geography Partner Schools (GPS). Geodika: Jurnal Kajian Ilmu Dan Pendidikan Geografi, 2(1), 1. https://doi.org/10.29408/geodika.v2i1. 865

United Nations Conventions on the Law of the Sea, Ocean Development and International Law (1982). https://doi.org/10.1080/009083295095 46068

Redaksi Tanjungpinang pos. 2018. Mangrova 2,8 Ha Dibabat. http://tanjungpinangpos.id/mangrove28-ha-dibabat/ (diakses 2019)

United Nations Conventions on the Law of the Sea, Ocean Development and International Law (1982). https://doi.org/10.1080/009083295095 46068 